\title{
ICT Tools Usage among Faculty of Education in Teaching Learning
}

\section{Processes}

\author{
Dr. M. Jagadesh ${ }^{1 *}$
}

\section{ABSTRACT}

Information and communication technologies (ICT) is defined, as a "diverse set of technological tools and resources used to communicate, and to create, disseminate, store, and manage information". The present study aims to study the usage of different ICT tools used by the faculty of Education in effective curriculum transaction. A rank analysis is done based on their responses to a data sheet. The emphasis of orientation and awareness programs for the faculty is signified in the study. To reach the goal of preparing teachers for effective technology use, a well-designed professional development program is essential. ICT can not only improve learning; but can also break down teacher and student stereotypes and boost self-esteem and would revolutionize the higher education system.

Keywords: ICT, Curriculum Transaction, Professional Development Program

Since the 1980s, the integration of computer technologies in education has been a challenge for many educational systems throughout the world. In educational reforms the teacher is the last but most crucial chain in the process of educational change. ICT stands for information and communication technologies and is defined, as a "diverse set of technological tools and resources used to communicate, and to create, disseminate, store, and manage information.”

To reach the goal of preparing teachers for effective technology use, a well-designed professional development program is essential. Professional development in a technological age requires new definitions and new resources. It cannot take the traditional forms of individual workshops or one-time training sessions. Instead, it must be viewed as an ongoing and integral part of teachers' professional lives.

As a result, the use of technology enables teachers to implement new teaching techniques, to help students work collaboratively and develop higher-order thinking skills, to encourage

\footnotetext{
${ }^{1}$ Assistant Professor, Dr. NGP College of Education, Coimbatore, Tamil Nadu, India *Responding Author

Received: January 31, 2017; Revision Received: February 18, 2017; Accepted: February 24, 2017

(C) 2017 Jagadesh M; licensee IJIP. This is an Open Access Research distributed under the terms of the Creative Commons Attribution License (www.creativecommons.org/licenses/by/2.0), which permits unrestricted use, distribution, and reproduction in any Medium, provided the original work is properly cited.
} 


\section{ICT Tools Usage among Faculty of Education in Teaching Learning Processes}

students to be engaged in the learning process, to assist students who have various learning styles and special needs, and to expose students to a broad range of information and experts.

\section{Background of the study}

Globally, there is a lack of research addressing the adoption of ICT in higher education and the effective use of hardware components of ICT used in teaching learning processes. In this study, the focus is on what is termed hardware - the components of ICT like the computer itself, storage media, and input and output devices. A teacher should have the pre-requisite competencies in handling these tools to quench the thirst of students with varied discipline and abilities. ICT is making it increasingly easy for teachers and students to have access to a broader range of materials than they can use in the classroom.

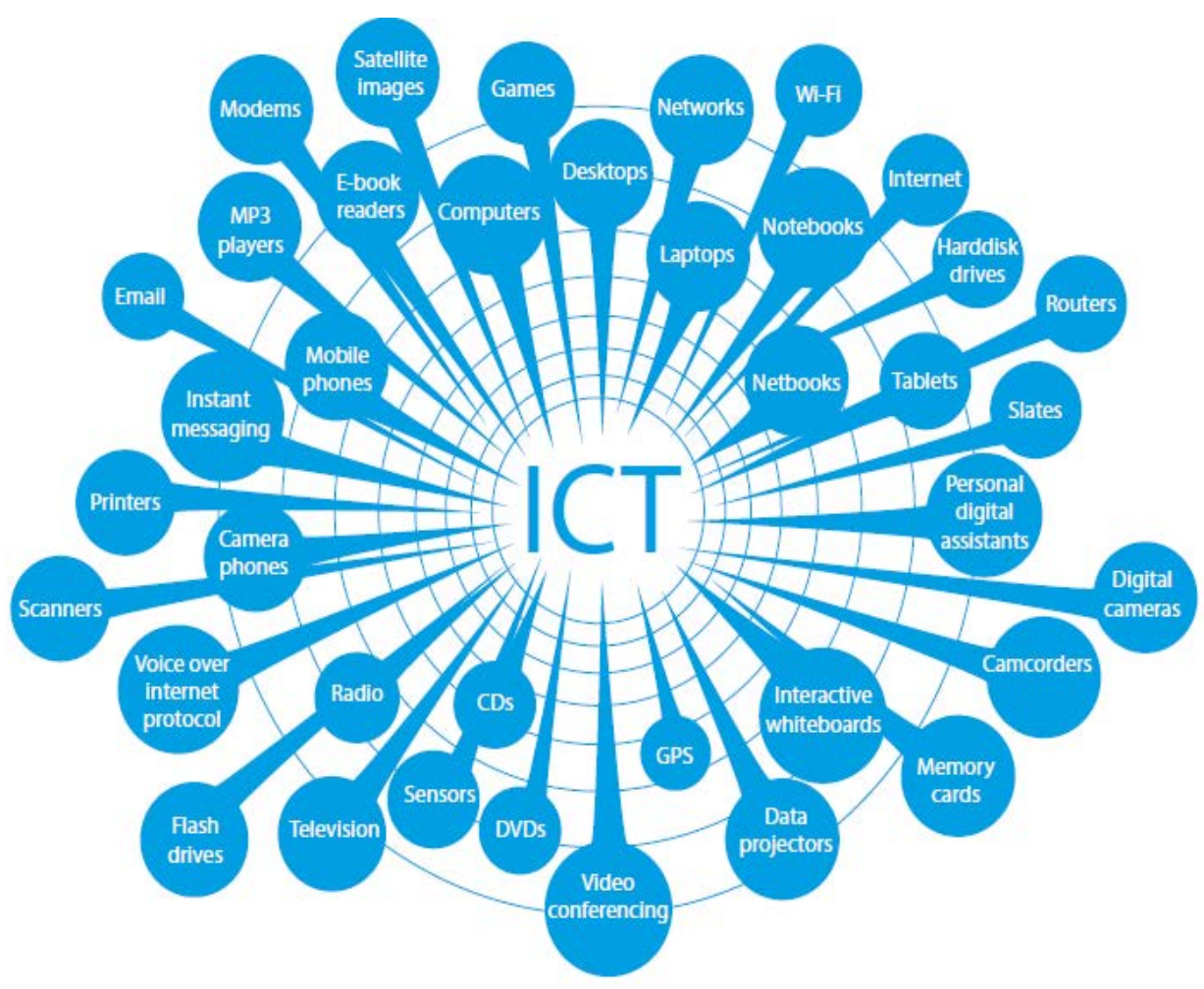

\section{Objectives of the present study}

1. To study the usage of ICT tools among faculty of Education in teaching learning process.

2. To rank the most used ICT tools by the faculty in effective curriculum transaction.

\section{METHODOLOGY}

Descriptive method is used in the present study. Eighty faculties from 22 colleges of Education were selected in random for the study. 


\section{ICT Tools Usage among Faculty of Education in Teaching Learning Processes}

\section{Tools used}

The tool is used to collect the personal information about the teachers. Here the information regarding the Age, Gender, Educational Qualification, Designation, and Teaching Experience, Administrative Duties held in institutions and Internet Access at home are collected. In addition, a tool containing different ICT tools is given. Teachers respond to it based on their experience and know-how of the ICT tools. After obtaining the responses, the usage of ICT tools were scored as "High", "Medium" and "Low".

\section{Table 1: Frequency and Percentage on Personal Variables}

\begin{tabular}{|c|c|c|c|c|}
\hline Sl.No & \multicolumn{2}{|l|}{ Variables } & Frequency & Percentage \\
\hline \multirow{2}{*}{1} & \multirow{2}{*}{ Gender } & Male & 37 & 46.25 \\
\hline & & Female & 43 & 53.75 \\
\hline \multirow{2}{*}{2} & \multirow{2}{*}{ Educational Qualification } & MEd & 49 & 61.25 \\
\hline & & MPhil/PhD & 31 & 38.75 \\
\hline \multirow{2}{*}{3} & \multirow{2}{*}{ Internet Access at home } & No & 21 & 26.25 \\
\hline & & Yes & 59 & 73.75 \\
\hline \multirow{3}{*}{4} & \multirow{3}{*}{ Age } & Upto 30 Years & 22 & 27.50 \\
\hline & & 31-39 Years & 34 & 42.50 \\
\hline & & 40 Years \& Above & 24 & 30 \\
\hline \multirow{3}{*}{5} & \multirow{3}{*}{ Designation } & Lecturer & 71 & 88.75 \\
\hline & & Assistant Professor & 2 & 2.50 \\
\hline & & Associate \& Professor & 7 & 8.75 \\
\hline \multirow{3}{*}{6} & \multirow{3}{*}{ Teaching Experience } & Upto 5 Years & 42 & 52.50 \\
\hline & & 6 to 10 Years & 26 & 32.5 \\
\hline & & Above 10 Years & 12 & 15 \\
\hline
\end{tabular}

Table 2: Rank Analysis on ICT tools usage

\begin{tabular}{|l|c|c|c|c|}
\hline \multicolumn{1}{|c|}{ Usage of ICT } & Sum & Mean & Std. Deviation & Rank \\
\hline Computer and Mobile Apps & 183 & 2.288 & 0.660 & 6 \\
\hline Email distribution list & 181 & 2.263 & 0.590 & 7 \\
\hline Web portals & 171 & 2.138 & 0.707 & 11 \\
\hline Windows Office (Word, Excel, Power point, Outlook) & 201 & 2.513 & 0.636 & 1 \\
\hline Podcast & 152 & 1.900 & 0.739 & 16 \\
\hline Blogs & 149 & 1.863 & 0.725 & 17 \\
\hline Video-streaming & 160 & 2.000 & 0.636 & 14 \\
\hline Local Area Network & 191 & 2.388 & 0.606 & 3 \\
\hline LCD & 199 & 2.488 & 0.574 & 2 \\
\hline Smart classrooms & 186 & 2.325 & 0.652 & 5 \\
\hline Interactive boards & 180 & 2.250 & 0.720 & 8 \\
\hline Network drives/ Cloud Computing & 159 & 1.988 & 0.755 & 15 \\
\hline Personal Digital Assistants & 161 & 2.013 & 0.755 & 13 \\
\hline GPS and GIS in Classrooms & 159 & 1.988 & 0.771 & 15 \\
\hline Portable Electronic Keyboards & 174 & 2.175 & 0.725 & 10 \\
\hline
\end{tabular}

(C) The International Journal of Indian Psychology, ISSN 2348-5396 (e)| ISSN: 2349-3429 (p) | 74 
ICT Tools Usage among Faculty of Education in Teaching Learning Processes

\begin{tabular}{|l|c|c|c|c|}
\hline \multicolumn{1}{|c|}{ Usage of ICT } & Sum & Mean & Std. Deviation & Rank \\
\hline Digital Cameras/ Scanners/ Printers & 190 & 2.375 & 0.663 & 4 \\
\hline Online Courses/ Tutorials & 165 & 2.063 & 0.663 & 12 \\
\hline Virtual labs & 165 & 2.063 & 0.735 & 12 \\
\hline E Books and Digital repositories & 179 & 2.238 & 0.680 & 9 \\
\hline Social Networks & 174 & 2.175 & 0.671 & 10 \\
\hline
\end{tabular}

\section{RESULTS AND DISCUSSION}

Based on the results of different ICT tools used by teachers, a rank analysis is made. Among the 20 ICT tools used by the faculty of Education, the usage of Windows office ranked the highest as it is found to be used commonly for curriculum transaction, presentations, e-assignments etc., it is followed by computers, mobile apps and digital scanners/printers. The least used ICT tools among the faculty are podcast, blogs and GPS/GIS technologies in classrooms. This reason could be the lack of awareness on these tools which has resulted in less penetration in usage. Proper training and orientation can make the usage of tools to the maximum.

\section{CONCLUSION}

ICT will be a key factor in future positive change - provided they are in the possession of people who use them creatively and for the common good. In the new Millennium, nations are judged by the well being of their citizens; level of education is one of the major determinants. Computer literacy of a nation in future will be a yardstick to measure the level of education.

\section{Acknowledgments}

The author appreciates all those who participated in the study and helped to facilitate the research process.

Conflict of Interests: The author declared no conflict of interests.

\section{REFERENCES}

Altun, S.A. \& Kalayc, E. et al., (2011). Integrating ICT at the faculty level: A case study. The Turkish Online Journal of Educational Technology, 10(4), 230-240.

Angad, G.R. (2014). Teachers' attitude towards information and communication technology (ICT). International Journal of Education and Psychological Research (IJEPR), 3(1), 21-23.

Askar, P. (2006). Logistic Regression Modeling for Predicting Task-Related ICT Use in Teaching. Educational Technology \& Society, v9 n2, 141-151.

Berge, Z. L. (1998). Barriers to online teaching in post-secondary institutions. Online Journal of Distance education Administration. 1(2). Summer.

Condie, R. (2013). Blending Online Learning with Traditional Approaches: Changing Practices. British Journal of Educational Technology, v38 n2, 337-348. 


\section{ICT Tools Usage among Faculty of Education in Teaching Learning Processes}

Hisham Barakat Hussein, (2011). Attitudes of Saudi universities faculty members towards using learning management system (JUSUR). The Turkish Online Journal of Educational Technology, 10(2), 43-53.

Jonassen, D. H., \& Reeves, T. C. (1996). Learning with technology: Using computers as cognitive tools. Handbook of research for educational communications and technology, 693-719. New York: Macmillan.

Keengwe, J. (2006). Faculty integration of computer technology into instruction and students' perceptions of computer use to improve their learning. Journal of Information Technology Education, 6, 169-180.

Schibeci, R. (2014). Teachers' Journeys towards Critical Use of ICT . Learning, Media and Technology, v33 n4, 313-327.

Selwood, I. (2005). Teacher Workload: Using ICT to Release Time to Teach. Educational Review, v57 n2, 163-174.

UNESCO. 2002a. Information and Communication Technologies in Teacher Education: A Planning Guide (Ed. P. Resta). UNESCO, Paris.

[Online]. Available:http://unesdoc.unesco.org/images/0012/001295/129533e.pdf

Wishart, J. (2012). PDAs and Handhelds: ICT at Your Side and Not in Your Face Technology. Pedagogy and Education, v16 n1, 95-110.

How to cite this article: Jagadesh M (2017), ICT Tools Usage among Faculty of Education in Teaching Learning Processes, International Journal of Indian Psychology, Volume 4, Issue 2, No. 92, ISSN:2348-5396 (e), ISSN:2349-3429 (p), DIP:18.01.108/20170402, ISBN:978-1-36578192-6 